\title{
BREAST CANCER PATIENTS' COMPLIANCE ON CHEMOTHERAPY: A DESCRIPTIVE STUDY
}

\author{
Vici Triyunita Sabiyanto ${ }^{1}$, Restuning Widiasih ${ }^{1}$, Tetti Solehati ${ }^{1}$ \\ ${ }^{1}$ Faculty of Nursing, Universitas Padjadjaran \\ Corresponding email: vicitriyunita@gmail.com
}

\begin{abstract}
Breast cancer is the most women cancer in the world, including Indonesia. Some patients stop breast cancer treatment which is impacted to patients' conditions. In chronic diseases, therapy compliance is important for reach successful therapy however study that assess breast cancer patients' compliance on chemotherapy is limited. The purpose of this study was to describe patient factors that can affect therapy compliance. This research used descriptive quantitative method and respondents were chosen using the accidental sampling technique. The data were gathered at one of the halfway houses in Bandung. Data were collected using a questionnaire. Data were analyzed by univariate analysis and described by frequency distribution. The results showed that 26 respondents $(84 \%)$ were obedient to chemotherapy. There were 28 respondents $(90.3 \%)$ because they did not carry out alternative medicine and 26 respondents (83.9\%) had because they put aside work and related affairs to do chemotherapy. In conclusion, the majority of respondents were obedient to chemotherapy. There are patient factors that can improve chemotherapy compliance, there are chosen therapy factor and demographic and economic factors. Development of another halfway houses could be carried out, because of the result of this research, representing many breast cancer patients feels easier to obedient the sequence of therapy.
\end{abstract}

Keywords: Breast cancer, therapy compliance, halfway house.

\section{INTRODUCTION}

Cancer is the leading cause of death in the world especially women. The incidence of breast cancer is more common in developing countries compared to more developed countries. There are as many as 883,000 cases in developing countries and as many as 794,000 cases in developed countries (Kementerian Kesehatan RI, 2016). Estimated number of breast cancer patients in Indonesia is 61,682 people $(0.5 \%)$. In addition, breast cancer is the highest prevalence of cancer in Indonesia (Kementerian Kesehatan RI, 2015). The estimated prevalence of breast cancer patients in West Java Province is 6,701 women or $0.3 \%$ (Kementerian Kesehatan RI, 2013).

Surgery, radiotherapy, chemotherapy and hormonal therapy are the treatment for breast cancer. Surgery treatment aims to lift cancer mass and to prevent complication. Radiation therapy aims to revive cell residues after surgical repair. 
Radiation therapy aims to destroy the remaining cancer cells after surgery. Radiation therapy is an act of cancer cells destruction through cytostatic medication into the patient's body. Other than that, hormonal therapy tries to control the hormones that trigger breast cancer (Kementerian Kesehatan RI, 2017).

The results of interviews with 6 breast cancer patients in one of the Regional Public Hospitals in West Java, data obtained about the patient's treatment history and found 4 people treated to the medical health facility. However, the treatment was not complete and let the symptoms occur until go back to the doctor when the symptoms interfere patient's daily activity. Commonly, patients preferred in traditional treatments. In addition, medical treatment requires a lot of money and the administration more complicated that needs enough time and energy. All patients were looked after by the patient's family.

Two other people said they had visited traditional treatment before going to medical treatments. When asked about how the traditional medicine works, patients said they had received an internal energy transfer and treatments based on patients' beliefs (religion). Appropriate therapy in breast cancer has an important role for patient's survival in the future. Compliance is an important component, considering the management of breast cancer takes a long time (Hu, Juarez, Yeboah \& Castillo, 2014 in Edi, 2015).

From previous studies, noncompliance (to follow the doctor's advice about taking recommended therapy) known, can cause disadvantage condition such as prolonged illness, worsen the patient's condition, the dependency of hospital care or home care, even more extreme, death (Edi, 2015). Based on the interview, we don't know the cause of therapy noncompliance, especially on patient factors.

Breast cancer is a chronic disease, management of this disease requires a long sequence and a long time. This condition susceptible to therapy noncompliance. Even though it is known, adherence to long-term therapy is very important to achieve successful therapy in chronic diseases (Edi, 2015). Compliance of patients in treatment is strongly influenced by factors from the patient's self, namely beliefs to recover, there are also other factors, namely symptoms that are felt to have diminished, socio- 
economic such as distance, costs, medical facilities and relationships with health professionals (Ayurini \& Parmitasari, 2015).

The halfway house is a place to stay while patients need to stay while waiting for therapy. They are usually free of profits. There is a halfway house that located in Bandung that accommodates patients to stay temporarily and wait for the turn of the therapy process in the hospital. Patients with chronic diseases (including breast cancer) stay there to wait their turn of breast cancer therapies. People who stay in the halfway house are the government health insurance patients. (Badan Penyelenggara Jaminan Sosial Kesehatan) BPJS or KIS (Kartu Indonesia Sehat) class 3. Patients who are staying in that halfway house, mostly take treatment at Hasan Sadikin Hospital (RSHS) Bandung. People could stay there but they need to show their identity card, family card, and class 3 BPJS or KIS member. The patient knows the halfway house through information conveyed by other patients. There were no nurses or another health worker at this halfway house, so there was minimal information regarding patients in the halfway house.

In chronic diseases including breast cancer, therapy compliance is important for reach successful therapy, however, studies that assess breast cancer patients' compliance on chemotherapy is limited. The purpose of this study was to describe patient factors that can affect therapy compliance.

\section{METHODS}

This research is a descriptive quantitative study. The variables therapy compliance factors in breast cancer patients who are in one of the halfway houses in Bandung. Determination of the sample in this study using accidental sampling technique. There were 31 respondents data collected using primary data. Respondents data were obtained by chemotherapy compliance questionnaire in cancer patients, which was developed by researcher Agustina (2015). There are 13 questions on the questionnaire and there are two alternative answers YES or NO.

The questionnaire instrument already tested by the previous researcher. The validity test results question number 9 must be revised and number 6 must be removed. The reliability test results show Cronbach alpha value 0.951, the number is greater than the critical number ( $\mathrm{r}$ table) of the value> 0.632 then the questionnaire is reliable. 
Vici Triyunita Sabiyanto : Breast Cancer Patients' Compliance on Chemotherapy

There are 2 categories in this study which are compliance and noncompliance. When the questionnaire score was $>6.5$ they grouped into compliance and non-compliance for score <6.5 This research has received a letter of approval from the Research Ethics Commission of the Faculty of Medicine, Padjadjaran University with letter number 214 / UN6.KEP / EC / 2019.

\section{RESULTS}

Characteristics in this study include age, place of residence, education status, occupation, income, marital status and stage of breast cancer.

Table 1 Characteristics of respondents

\begin{tabular}{|c|c|c|}
\hline No. & Respondents & $\begin{array}{l}\text { Frequency (f) and Percentage } \\
(\%)\end{array}$ \\
\hline \multirow[t]{4}{*}{1.} & Age & \\
\hline & $<20$ years & $0(0 \%)$ \\
\hline & $20-35$ years & $1(3.2 \%)$ \\
\hline & $>35$ years & $30(96.8 \%)$ \\
\hline \multirow[t]{3}{*}{2.} & Place of Residence & \\
\hline & Rural & $30(96.8 \%)$ \\
\hline & City & $1(3.2 \%)$ \\
\hline \multirow[t]{6}{*}{3.} & Educational status & \\
\hline & Uneducated & $1(3.2 \%)$ \\
\hline & Elementary school & $20(64.5 \%)$ \\
\hline & Junior high school & $6(19.4 \%)$ \\
\hline & High school & $3(9.7 \%)$ \\
\hline & College & $1(3.2 \%)$ \\
\hline \multirow[t]{3}{*}{4.} & Occupation & \\
\hline & Employment & $1(3.2 \%)$ \\
\hline & Unemployment & $30(96.8 \%)$ \\
\hline \multirow[t]{3}{*}{5.} & Income & \\
\hline & Earning & $1(3.2 \%)$ \\
\hline & Not earning & $30(96.8 \%)$ \\
\hline \multirow[t]{3}{*}{6.} & Marital status & \\
\hline & Married & $29(93.5 \%)$ \\
\hline & Unmarried & $2(6.5 \%)$ \\
\hline \multirow[t]{6}{*}{7.} & B reast cancer stage & \\
\hline & Stage 1 & 0 \\
\hline & Stage 2 & $10(32.3 \%)$ \\
\hline & Stage 3 & $17(54.8 \%)$ \\
\hline & Stage 4 & 0 \\
\hline & Unknown & $4(12.9 \%)$ \\
\hline
\end{tabular}


Vici Triyunita Sabiyanto : Breast Cancer Patients' Compliance on Chemotherapy

Table 2 Patients' Compliance

\begin{tabular}{ll}
\hline Compliance & Frequency (f) and Percentage (\%) \\
\hline Compliance & $26(84 \%)$ \\
Non Compliance & $5(16 \%)$ \\
\hline Total & $31(100 \%)$
\end{tabular}

Table 3 Chemotherapy Compliance based on Patient Factors

\begin{tabular}{|c|c|c|c|}
\hline \multirow[b]{2}{*}{ No. } & \multirow{2}{*}{$\begin{array}{l}\text { The Factors of Chemotherapy } \\
\text { Compliance based on Patient } \\
\text { Factors }\end{array}$} & \multicolumn{2}{|c|}{ Frequency (f) and Percentage (\%) } \\
\hline & & Compliance & $\begin{array}{l}\text { Non } \\
\text { Compliance } \\
\end{array}$ \\
\hline \multirow[t]{4}{*}{1.} & $\begin{array}{l}\text { Demographic and economic } \\
\text { factors }\end{array}$ & & \\
\hline & - Activities & $26(83.9 \%)$ & $5(16.1 \%)$ \\
\hline & - Transportation cost & $23(74.2 \%)$ & $8(25.8 \%)$ \\
\hline & $\begin{array}{l}\text { Long-distance from the } \\
\text { health facility }\end{array}$ & $19(61.3 \%)$ & $12(38.7 \%)$ \\
\hline \multicolumn{4}{|c|}{ 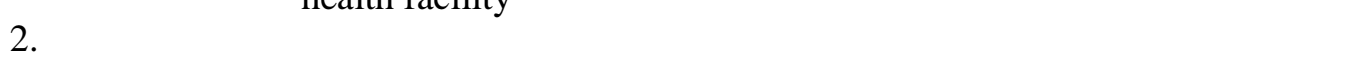 } \\
\hline & $\begin{array}{l}\text { Schedule conformity factor } \\
-\quad \text { Chemotherapy schedule }\end{array}$ & $24(77.4 \%)$ & $7(22.6 \%)$ \\
\hline 3. & $\begin{array}{l}\text { Physical condition factor } \\
\text { - The negative effect felt } \\
\text { by the body }\end{array}$ & $23(74.2 \%)$ & $8(25.8 \%)$ \\
\hline 4. & $\begin{array}{l}\text { Chosen treatment factor } \\
-\quad \text { Alternative treatment }\end{array}$ & $28(90.3 \%)$ & $3(9.7 \%)$ \\
\hline 5. & $\begin{array}{cl}\text { Patient's mind factors } \\
\text { - } & \text { Motivation } \\
- & \text { Perception }\end{array}$ & $\begin{array}{l}19(61.3 \%) \\
23(74.2 \%)\end{array}$ & $\begin{array}{l}12(38.7 \%) \\
8(25.8 \%)\end{array}$ \\
\hline
\end{tabular}

The majority of breast cancer patients 30 respondents (96.8\%) aged over 35 years, 30 respondents $(96.8 \%)$ residing in the rural, 20 respondents $(64.5 \%)$ were last educated in elementary school, 30 respondents (96.8\%) were unemployment or housewives, 30 respondents (96.8\%) were not earning, 29 respondents (93.5\%) were married and respondents with breast cancer stage 3 as many as 17 respondents $(54.8 \%)$.

In the demographic and economic factors, most of the 26 patients $(83.9 \%)$ were obedient to chemotherapy despite other activities. In the schedule suitability factor, there were $24(77.4 \%)$ respondents who adhered to chemotherapy and did not 
make the schedule an excuse. In the physical condition factor, there were 23 (74.2\%) respondents who obedient to chemotherapy and the bad effects on the body did not become obstacles. In the chosen treatment factor, as many as 28 (90.3\%) respondents obeyed chemotherapy because they did take out alternative therapy. On the factors in the patient's mind, $23(74.2 \%)$ respondents obeyed chemotherapy, always followed chemotherapy on schedule and never forgot the chemotherapy schedule.

\section{DISCUSSION}

The results showed that 26 respondents $(84 \%)$ were obedient to chemotherapy. But there are still 5 respondents (16\%) who are not obedient to chemotherapy. Based on the theory of the World Health Organization (WHO) five patient factors can affect compliance in this study. These factors consist of factors of demographic and economic conditions, schedule suitability factors, physical condition factors, chosen treatment factors and factors in the patient's mind.

Based on the results of the respondent's characteristics, there were a majority of patients aged > 35 years. This is related to the incidence of breast cancer will increase rapidly in reproductive age (1-49 years according to the Departemen Kesehatan, 2004) (Indrati, Setyawan, \& Handojo, 2005). Reinforced by the results of research that states age has a 4 times greater risk of breast cancer, and the increasing age, the greater the risk of breast cancer (Fitoni, 2012). There are results of research that in respondents aged 17-45 years (100\%) obediently do chemotherapy (Nurdjanah, 2015). But there is still the possibility of breast cancer in women aged 20-35 years, indicated by the number 1 person (3.2\%) affected by breast cancer in this study. Seeing this, women of productive age (15-49 years) should be aware of reproductive health from an early age by breast self-examination (BSE). Regarding the results of the research that states that early detection and screening programs can help improve survival rates in women at risk for breast cancer (Karimi, Delpisheh, Sayehmiri, Saboori, \& Rahimi, 2014).

The majority of respondents in the study lived in the village (rural background). It is known that long distances to health facilities can prevent someone from obtaining health services (Widyastuti, 2016). So that information on breast cancer both promotive, preventive, curative and rehabilitative is less exposed to the village 
community. Supported by the results of the study, there is a significant relationship between health services and distance factors (Halimatussakdiah \& Junardi, 2017). In addition, there were $1(3.2 \%)$ research respondents residing in the city. This shows that people may reside in cities with breast cancer. Therefore, counseling on breast cancer needs to be maintained and even improved in both rural and urban areas.

Most of the respondent patients attended elementary school (SD). Several of them attended 6 junior high schools (19.4\%), 3 high schools (SMA) (9.7\%), there was 1 person (3.2\%) in College and 1 person (3.2\%) uneducated. This is supported by the statement that the higher level of education, will affect someone's knowledge, so that it will also affect someone to behave, in receiving information and encouraging healthy behavior (Notoatmodjo, 2012). Therefore, someone will receive information and encourage healthy behavior if the level of education is higher because it will affect one's knowledge in receiving information (Sagita, 2013). Supported also on the results of research that states, the high and low knowledge of women in childbearing age, will influence breast cancer prevention efforts (Sumiatin, 2013). There is a high percentage of compliance research results in highly educated respondents (Budiman, Khambri, \& Bachtiar, 2013). Looking at these data, it is better if health education, especially breast cancer, is presented as early as possible, for example in schools, for teenage women.

Almost all respondents in this study were housewives. Only 1 person (3.2\%) that had a job. Karima \& Wahyono (2013) stated the type of work is one of the factors that can increase the risk of breast cancer. This is caused by exposure to carcinogenic substances in the environment such as polycyclic aromatic hydrocarbons (PAH), pesticides, metals, chemical and textile industries (Khonsa, 2018). The data has a match with the results of the study which shows that most breast cancer patients in Ciptomangunkusumo Hospital were unemployment (70.6\%) (Sagita, 2013). In contrast to the data from these studies, breast cancer can also attack housewives who are not even exposed to carcinogenic substances. There are results of research which state that high compliance rates can be found in the employment status of housewives (82.35\%) (Nurdjanah, 2015). In this study, the type of work the respondents did was not assessed. Further research is needed which is more specific to link the types of work with the incidence of cancer, especially breast cancer. 
Breast cancer patients who are had not earnings are the majority in this study. A total of 30 respondents $(96.8 \%)$ were women without income. There are income respondents because respondents are working women, indicated by only 1 respondent $(3.2 \%)$ in this study. This is continuous with employment status because the majority of respondents are housewives. The data in this study are in line with the results of the study stating that there is a relationship between income and the risk of breast cancer incidence (Yulianti, 2010). Increased income affects improving health and other family conditions, the higher the income, the greater the percentage used to buy fruit, vegetables and other types of food (Yulianti, 2010). The lower the socio-economic level of a person, the less compliant for treatment (Budiman, Khambri, \& Bachtiar, 2013). It has been known that frequent consumption of fiber sources can be a protective factor against the incidence of breast cancer (Indrati, Setyawan, \& Handojo, 2005). Supported by research by Maryani and Muliani (2010), people with low economic status usually lack understanding of health, are unable to buy nutritious food, cannot afford medicine and access health services (in Nurdjanah, 2015).

The marital status respondents in this study, the majority were married women, and there were not married only 2 respondents $(6.5 \%)$. It is known that women who are married, have children and breastfeed their children, have a lower risk of breast cancer. This is because there is a perfect differentiation of her breasts and will reduce the risk of breast cancer incidence (Fitoni, 2012). In addition, for married women, there is a high probability of using hormonal contraception. It is known that oral contraceptives increase the risk of developing breast cancer (Smeltzer, Barre, Hinkle, \& Cheever, 2002). Supported by the results of the research statement, women using hormonal contraceptives were 1.66 times more at risk for breast cancer (Awaliyah, Pradjatmo, \& Kusnanto, 2017). It is also known that there is a relationship between estrogen exposure to the development of breast cancer (Smeltzer, Barre, Hinkle, \& Cheever, 2002). The risk of breast cancer can be minimized by reducing the use of hormonal contraception to a non-hormonal contraceptive. Or the use of hormonal contraceptives that are adjusted to the body condition of each individual. In this study, reproductive history was not assessed such as; the history of having children, breastfeeding and using contraception. More in-depth research could be done related to the analysis of the reproductive history of having children, breastfeeding and the type of contraception used. 
More than half of the respondents were breast cancer patients with stage 3 . The rest were varied, 10 respondents $(32.3 \%)$ were stage 2 breast cancer patients and 4 respondents $(12.9 \%)$ didn't know the stage of breast cancer they suffered. Patients don't know the stage because the doctor doesn't tell the stage of their breast cancer. Chemotherapy is a management that is often done in cancer patients, including breast cancer. Current chemotherapy management, not always based on breast cancer stage, but adjusted to the patient's condition. The latest clinical examination of patients that determines what treatment can achieve the best results (Smeltzer, Barre, Hinkle, \& Cheever, 2002). In line with the results of other studies, protocol-based therapies based on the stage have changed to personalized treatment. This was done taking into account the prognostic and predictive factors of each patient (Ramli, 2015). Therefore, treatment with chemotherapy can be done at any stage, as in the results of this study.

\section{Chemotherapy Compliance of Breast Cancer Patients in One Shelter in Bandung}

Based on the results of the study it was found that the majority of respondents were obedient in chemotherapy. This happened because of various reasons expressed by respondents, such as; access to treatment became easier, the administration that done by the halfway house administrator, the place to stay and the patient's caregiver's needs are born by the halfway house. This explanation, allowing patients to easily adhere to the series of therapies recommended by the doctor. But there are still 5 respondents $(16 \%)$ who are not obedient to undergoing chemotherapy. This number is caused by factors that can affect the compliance of chemotherapy previously mentioned. It was previously known that adherence to long-term therapy is very important for the reached success of therapy in chronic diseases (Edi, 2015).

Non-compliance brings many effects, such as slowing down the healing process, worsening the patient's condition and even death (Ayurini \& Parmitasari, 2015). In addition, according to the WHO theory, non-compliance can pose a high risk of toxicity as well as drug resistance. Non-compliance also creates another problem, namely the use of higher costs. Continuous counseling is needed between patients and health workers so that barriers that can lead to non-compliance with chemotherapy were explored. Continuous counseling in 5 non-compliance patients, expected to increase awareness of chemotherapy. 


\section{Therapy Compliance Factors in Breast Cancer Patients in one of halfway house in Bandung}

This study examines factors that can influence chemotherapy compliance based on patient factors, according to WHO standards. These factors are demographic and economic, schedule suitability factors, physical condition factors, chosen treatment factors and factors in the patient's mind. In demographic and economic factors, 3 factors can affect compliance, there are constraints because there are other activities, transportation costs and long distances from the health facility. The results showed that 26 respondents $(83.9 \%)$ were compliance with chemotherapy despite the patient's had other activities. Therapy compliance is influenced by one of the socio-economic factors. In theory, low socioeconomic status can affect someone's compliance with therapy (WHO, 2003). In addition, some studies state that the lower a person's socioeconomy, the more non-compliance in treatment (Budiman, Khambri, \& Bachtiar, 2013). But this was not proven in this study, because of the majority of respondents compliance to chemotherapy, even with low economic status. As many as 23 respondents $(74.2 \%)$ were obedient to chemotherapy even though there were obstacles in transportation costs. However, there are still 8 respondents who are not compliance to chemotherapy because of constrained transportation costs. As in the research that states, the cost of accommodation during treatment, family needs during treatment and long-term medical expenses, is a problem in chemotherapy compliance (Halimatussakdiah \& Junardi, 2017). The long-distance to a health facility can be a problem for someone to get health services (Widyastuti, 2016). However, this statement is not in line with the results of this study, as many as 19 respondents (61.3\%) remained compliance to chemotherapy, even though the residence was far from the health facility. The reason for this was revealed because patients (who came from the village and were referred from beyond Bandung city) could stay at the half while waiting for the treatment process. That could be reducing the patient's burden in continuing breast cancer treatment.

In the schedule conformity factor, there were 24 respondents (77.4\%) compliance with chemotherapy on a schedule determined by the doctor. The high level of compliance chemotherapy in this study can be caused by respondents being BPJS insurance patients. This is related to research that states, there was a relation, about 
health insurance availability and compliance therapy (Budiman, Khambri, \& Bachtiar, 2013). Supported by another study results, the increase compliance to therapy, because of the guaranteed cost of care from health insurance (Edi, 2015). But still, 7 respondents $(22.6 \%)$ did not comply with the chemotherapy schedule. This happened because respondents who did not know the chemotherapy schedule or respondents who did not register directly to the hospital when near chemotherapy schedule. Patients revealed the late chemotherapy because there were very long queues of BPJS patients so the chemotherapy carried out on several weeks later. In addition, there is a need for patient's readiness before chemotherapy treatments begin.

In the physical condition factor, the negative side effects of chemotherapy did not make the majority of respondents negligent in undergoing chemotherapy. Shown by the numbers, most of the 23 respondents (74.2\%) remained compliance through chemotherapy, even though there were complaints of negative drug side effects on the body, which made respondents unable to do their usual activities. There are still a small number of 8 respondents (25.8\%) who did not complete chemotherapy because they felt negative side effects on the body. This is match with the theory that the severity of symptoms or illness and levels of helplessness (physical, psychological and social) can affect therapy adherence (WHO, 2003). In addition to the results of previous studies, there was a significant relationship between the side effects of chemotherapy to chemotherapy compliance in breast cancer patients (Halimatussakdiah \& Junardi, 2017). Supported by another research by Mindachew, et al (2011) and research by Fürthauer, Flamm and Sönnichen (2013) (in Edi, 2015), that patients' fear of side effects and unwanted events from drugs is the cause of noncompliance therapy. On the other side, stated that there was no relation between side effects and compliance (Budiman, Khambri, \& Bachtiar, 2013).

Twenty-eight respondents $(90.3 \%)$ compliance with chemotherapy treatment and did not carry out alternative medicine. Respondent revealed, that more trust in medical treatment, so they adherence to medical treatment. In addition, respondents expressed their enthusiasm for the medical treatment recommended by the doctor, because of the desire to recover. While 3 respondents $(9.7 \%)$ were not compliance to chemotherapy because they had alternative treatment before, so they did not follow the prescribed chemotherapy. The same opinion based on the results of research states that 
breast cancer patients often not compliance to treatment cause various reasons such as cost problems and want to try alternative medicine, Samuel (2011) (Halimatussakdiah \& Junardi, 2017).

In the patient's mind factor, most respondents compliance and did not experience motivational constraints during chemotherapy. A total of 19 respondents $(61.3 \%)$ adherence to chemotherapy. Respondents said that they were very motivated to recover and could activity like before. In addition, the family is a strong reason for patients to be motivated to recover from breast cancer. The expression is in line with the research, there is a significant relationship between family support and motivation of breast cancer patients in carrying out chemotherapy (Halimatussakdiah \& Junardi, 2017). Supported by the results of studies that state, there is a relationship between partner support to chemotherapy compliance (Agustina, 2015). Also supported by the WHO theory, motivation is one of the factors that affect patient adherence to therapy. In addition, there were 23 respondents (74.2\%) who were compliance with chemotherapy because they always followed the prescribed chemotherapy schedule and never forgot the prescribed chemotherapy schedule. This is because of the patient's motivation to recover is that the respondent always follows the chemotherapy schedule and does not forget the date of chemotherapy. There were still 8 respondents $(25.8 \%)$ who were not compliance to chemotherapy because they did not do chemotherapy on schedule and had forgotten about the chemotherapy schedule. This is related to patient perceptions. If there is a high perception of susceptibility to disease, it will also be someone's high level of healthy behavior (Notoatmodjo, 2012). Supported by another research that states, behavior that arises from self, is determined by someone's perception. Decisions in the use of utilizing health facilities indicate the need for treatment (Primanita, 2011). Compliance to treatment is influenced by the patient's perception of the severity of the disease, such as; clinical improvement, loss of pain symptoms, perception as if it has been cured (Edi, 2015).

\section{CONCLUSION}

The results showed that the majority of respondents were in compliance with chemotherapy. There are patient factors that can affect adherence to therapy, including; 
demographic and economic factors, schedule suitability factors, physical condition factors, chosen treatment factors and factors in the patient's mind. Treatment factors and demographic and economic factors were the strongest reasons for compliance with chemotherapy in breast cancer patients in one of the halfway house in Bandung. Longdistance and patient motivation are two sub-factors that are the biggest causes of noncompliance in this study. Further research could be done such as qualitative research on factors that can affect compliance, not just from patient factors. Research would also about factors that affect patients' compliance.

\section{REFERENCES}

Agustina, N. (2015). Hubungan Dukungan Pasangan dengan Kepatuhan Menjalani Kemoterapi pada Pasien Kanker di Ruang Mamplam III Rumah Sakit

Umum Daerah dr. Zainoel Abidin Banda Aceh. Banda Aceh: Universitas Syiah Kuala.

Awaliyah, N., Pradjatmo, H., \& Kusnanto, H. (2017). Penggunaan Kontrasepsi Hormonal dan Kejadian Kanker Payudara di Rumah Sakit Dr. Sarjito.

Berita Kedokteran Masyarakat, $\quad$ Volume 33 Nomor 10, pp. 487- 494, 1 Oktober.

Ayurini, R., \& Parmitasari, D. (2015). Kepatuhan Pengobatan pada Pasien Kanker. Psikodemensia, Vol: 14/2, (83-95).

Budiman, A., Khambri, D., \& Bachtiar, H. (2013). Faktor yang Mempengaruhi

Kepatuhan Berobat Pasien yang Diterapi dengan Tamoxifen Setelah Operasi Kanker Payudara. Jurnal Kesehatan Andalas.

Edi, I. S. (2015). Faktor-faktor yang Mempengaruhi Kepatuhan Pasien pada Pengobatan: Telaah Sistematik. Medicamento, Vol: 1, No:1.

Fitoni, H. (2012). Faktor Risiko Kanker Payudara di RSUD dr. Soedarso Pontianak. Pontianak: Universitas Tanjungpura.

Halimatussakdiah, \& Junardi. (2017). Faktor Risiko Kepatuhan Kemoterapi pada Pasien Kanker Payudara. Jurnal Kesehatan, Volume VIII, Nomor 3, 415-424.

Indrati, R., Setyawan, H., \& Handojo, $\quad$ D. (2005). Faktor-faktor Risiko yang

Berpengaruh terhadap Kejadian Kanker Payudara Wanita. Semarang: Universitas Diponegoro.

Karima, U. Q., \& Wahyono, T. Y. （2013). Faktor-faktor yang Berhubungan dengan Kejadian Kanker Payudara Wanitadi Rumah Sakit Umum Pusat Nasional (RSUPN) dr. Cipto Mangunkusumo Jakarta Tahun 2013. Depok: Universitas Indonesia. 
Vici Triyunita Sabiyanto : Breast Cancer Patients' Compliance on Chemotherapy

Karimi, A., Delpisheh, A., Sayehmiri, K., Saboori, H., \& Rahimi, E. (2014). Predictive Factors of Survival Time of Breast Cancer in Kurdistan Province of Iran between 2006-2014: A Cox Regression Approach. Asian Pacific Journal of Cancer Prevention, Vol 15.

Kementerian Kesehatan RI. (2015). Buletin Jendela Data dan Informasi Kesehatan. Jakarta: Pusat Data dan Informasi, Kementerian Kesehatan RI.

Kementerian Kesehatan RI. (2017). Kementerian Kesehatan ajak Masyarakat Cegah dan Kendalikan Kanker. World Summit Against Cancerfor the New Millenium. Jakarta: Biro Komunikasi dan Pelayanan Masyarakat, Kementerian Kesehatan RI.

Kementerian Kesehatan RI. (2017). Pedoman Nasional Pelayanan Kedokteran Kanker Payudara. Jakarta: Komite Penanggulangan KankerNasional,

Kementerian Kesehatan RI.

Kementerian Kesehatan, R. (2013). $\quad$ Riset Kesehatan Dasar. Jakarta: Badan Penelitian dan Pengembangan Kesehatan, Kementerian Kesehatan RI.

Kementerian Kesehatan, R. (2016). Bulan Peduli Kanker Payudara. Jakarta: Pusat Data dan Informasi, Kementerian Kesehatan RI.

Khonsa. (2018). Hubungan Antara Usia dan Pekerjaan dengan Subtipe Molekuler HER-2 pada Pasien Invasive Breast Carcinoma of No Special Type (NST) di RS PKU Muhammadiyah Surakarta. Surakarta:

Universitas Muhammadiyah Surakarta.

Notoatmodjo, S. (2012). Promosi Kesehatan dan Perilaku Kesehatan. Jakarta: Rineka Cipta.

Nurdjanah, S. (2015). Hubungan Dukungan Keluarga dengan Kepatuhan Pelaksanaan Program Kemoterapi pada Klien Kanker Payudara di RSUP Dr. Sardjito Yogyakarta. Yogyakarta: Sekolah Tinggi Ilmu Kesehatan 'Aisyiyah.

Primanita, A. (2011). Hubungan Antara Persepsi tentang Sakit dengan Pemanfaatan Pelayanan Kesehatanoleh Peserta Jaminan Kesehatan Masyarakat di Puskesmas Gunungpati Kota Semarang. Semarang:

Universitas Negeri Semarang.

Ramli, M. (2015). Update Breast Cancer Management Diagnostic and Treatment. Majalah Kedokteran Andalas, Vol. 38, No. Supl. 1.

Sagita, S. (2013). Analisis Hubungan Tingkat Pendidikan Pasien dengan Kanker Payudara Stadium Dini di Instalasi Rawat Inap Rumah Sakit Indonesia. Ciptomangunkusumo Jakarta Tahun 2012. Jakarta: Universitas

Smeltzer, S. C., Barre, B. G., Hinkle, J. L., \& Cheever, K. H. (2002). Brunner \& Suddarth's Textbook of Medical Surgical Nursing. Jakarta: Penerbit Buku Kedokteran EGC. 
Vici Triyunita Sabiyanto : Breast Cancer Patients' Compliance on Chemotherapy

Sumiatin, T. (2013). Hubungan Pengetahuan dengan Upaya Pencegahan Kanker Payudara pada Wanita Usia Subur di Kecamatan Semanding Kabupaten

Tuban. Jurnal Keperawatan Universitas Muhammadiyah Malang, ISSN 2086-3071, Juli, Vol. 4, No. 2, 152-159.

WHO. (2003). Adherence to Long-term Therapies: Evidence for Action. Switzerland: WHO Library Cataloguing-in Publication Data.

Widyastuti, H. (2016). Faktor-faktor yang Berhubungan dengan Kepatuhan Berobat TB Paru di Balai Kesehatan Paru Masyarakat Kota Pekalongan. Pekalongan: Universitas Negeri Semarang.

Yulianti, S. (2010). Faktor-faktor yang Berhubungan dengan Kejadian Kanker Payudara di RSUP dr. Wahidin Sudirohusodo Makassar. Makassar: Universitas Islam Negeri Alauddin. 